\title{
Entrepreneurial Intentions of University Students: An International Comparison between African, European and Canadian Students ${ }^{1}$
}

Étienne St-Jean ${ }^{2}$, Ph.D., Professor, Research Institute on SMEs, University of Québec at Trois-Rivières, 3351, boul. des Forges, Trois-Rivières (Québec), Canada, G9A 5H7. Email: etienne.st-jean@uqtr.ca, Tel: 1-819-376-5011 \#4293.

Aziz Nafa, Economist-researcher, Centre de Recherche en Économie Appliquée pour le Développement (CREAD), division Firmes et Économie Industrielle, BP 187 - Rostomia

- Bouzaréah - Alger - Algeria. Email: aziznafa@gmail.com, Tel.: + 213021941272.

Maripier Tremblay, DBA, Professor, Université Laval, Faculté des sciences de l'administration, Pavillon Palasis-Prince, local 1523, Québec (Québec), G1V 0A6. Email: Maripier.Tremblay@fsa.ulaval.ca, Tel: 1-418-656-2131, \# 4961.

Frank Janssen, Ph.D., Professor, Louvain School of Management, Université Catholique de Louvain, Place des Doyens, 1, 1348 Louvain-La-Neuve, Belgium. Email: frank.janssen@uclouvain.be, Tel.: +32 (0)10 478428.

Jacques Baronet, Ph.D., Professor, Université de Sherbrooke, 2500, boul. de l'Université, Sherbrooke (Québec) Canada, J1K 2R1. Jacques.Baronet@USherbrooke.ca, Tel.: 1-819-821-8000, \# 63050. Email:

Christophe Loué, Ph.D., Professor-researcher, NOVANCIA, 3 rue Armand Moisant, Paris (France) 15 ${ }^{\text {ème }}$, Email: cloue@novancia.fr, Tel.: 06.63.60.46.18.

\begin{abstract}
The purpose of this study is to compare the entrepreneurial intentions of university students in North Africa (Algeria) with those of students in Canada and Europe (France and Belgium), and to examine differences with regard to psychological, sociocultural and economic factors influencing these intentions. Analyses on the sample as a whole confirm the relevancy of the theory of planned behaviour (TPB) proposed by Ajzen (1991). When we differentiate among cultural groups, results were fairly similar for Canadian and European students. However, no TPB elements were significant for the Algerian students, or more significant than the control variables. We discuss the need to consider cultural factors to explain entrepreneurial intentions. Moreover, given the socioeconomic climate in Algeria, we hypothesize that among Algerian university students, entrepreneurship is motivated by necessity rather than opportunity.
\end{abstract}

\footnotetext{
${ }^{1}$ É. St-Jean, A. Nafa, M. Tremblay, F. Janssen, J. Baronet and C. Loué (2014), “Entrepreneurial Intentions of University Students: An International Comparison between African, European and Canadian students", International Journal of Entrepreneurship and Innovation Management, 18, no. 2/3, p. 95-114.

${ }^{2}$ Corresponding author.
} 
Keywords: Youth entrepreneurship; university students; entrepreneurial intentions; international comparisons; theory of planned behaviour; self-efficacy; attitudes; subjective norms; cultural differences; Algeria; France; Belgium; Canada;

Étienne St-Jean, Ph.D. holds the UQTR Research Chair on the Entrepreneurial Career. He is a regular member of the Research Institute on SMEs at the Université du Québec at Trois-Rivières and also a regular member of the Centre de Recherche Interdisciplinaire sur les PME et l'entrepreneuriat. He is co-director of the Canadian Council for Small Business \& Entrepreneurship (CCSBE) and member of the Editorial Advisory Board of Entrepreneurial Practice Review. His research interests are in the development support for entrepreneurs through mentoring, entrepreneurial career and personality and SMEs strategic choices in the forestry sector.

Aziz Nafa is permanent researcher at the Centre de Recherche en Économie Appliquée pour le Développement (Research Centre of Applied Economics for Development) (CREAD) in Algiers (Algeria). His research focuses on entrepreneurship and economic development. After studying the use of ICT in the activities of young entrepreneurs and entrepreneurship students, he devoted himself to the role of the diaspora in the initiative of innovative companies in the country (the case of Algeria).

Maripier Tremblay, DBA, is professor at the Faculty of Business Administration and Director of the Chair in Entrepreneurship and Innovation at Université Laval, in Québec, Canada. Specialized in entrepreneurship, her main research interests focus on opportunity recognition, creativity, entrepreneurs of the new generations and entrepreneurial intentions. Alone or in collaboration, she has published several scientific articles and collaborated in many books. She teaches undergraduate and graduate entrepreneurship courses, including transmission and business succession.

Dr. Frank Janssen is professor of entrepreneurship at the Louvain School of Management of the Université catholique de Louvain (UCL) in Belgium where he runs the interdisciplinary program in entrepreneurship (CPME). He is invited professor at EDHEC Business School (France) and has been a short-term visiting professor in American, African, Asian and European universities. He is a senior member of CRECIS (Centre for Research on Entrepreneurial Change and Innovative Strategies) and the vice-president of the International French-speaking Research Association on SMEs and Entrepreneurship (AIREPME). His research interests and recent publications are in the fields of firm growth, corporate governance in SMEs, social entrepreneurship, entrepreneurial motivations, entrepreneurship and regulation, research methods in entrepreneurship, as well as entrepreneurial pedagogy.

Dr. Jacques Baronet is Full Professor at Université de Sherbrooke. Before his academic career, he held management positions for 15 years. His research and teaching interests include creativity, venture start-up, entrepreneurial skills, and corporate entrepreneurship. 
He studies science and technology entrepreneurship and the impact of regions on innovation, entrepreneurship and corporate entrepreneurship. He is a founding member of the Innovation Management Research Team at his home university and of the Boosting Entrepreneurship Skills and Training in Genomics research consortium in Canada. Furthermore he cofounded a regional action research group on entrepreneurial culture and serves on the scientific and research committees of two business schools in Australia and France.

Dr. Christophe Loué is Professor and Researcher at Novancia Business School (Paris). He took up his post as professor at the school after having spent several years as a junior consultant at the Paris CCI's Directorate of Human Resources. Professor Loué is responsible for courses in Human Resources Management in Novancia's Bachelor's and Master's programs. His current research focuses on the identification of entrepreneurial skills, the acquisition of competences by the students and the measure of their entrepreneurial intention and self-efficacy in pedagogical situations. 


\title{
Entrepreneurial Intentions of University Students: An International Comparison between African, European and Canadian Students
}

\begin{abstract}
The purpose of this study is to compare the entrepreneurial intentions of university students in North Africa (Algeria) with those of students in Canada and Europe (France and Belgium), and to examine differences with regard to psychological, sociocultural and economic factors influencing these intentions. Analyses on the sample as a whole confirm the relevancy of the theory of planned behaviour (TPB) proposed by Ajzen (1991). When we differentiate among cultural groups, results were fairly similar for Canadian and European students. However, no TPB elements were significant for the Algerian students, or more significant than the control variables. We discuss the need to consider cultural factors to explain entrepreneurial intentions. Moreover, given the socioeconomic climate in Algeria, we hypothesize that among Algerian university students, entrepreneurship is motivated by necessity rather than opportunity.
\end{abstract}

Keywords: Youth entrepreneurship; university students; entrepreneurial intentions; international comparisons; theory of planned behaviour; self-efficacy; attitudes; subjective norms; cultural differences; Algeria; France; Belgium; Canada; 


\section{Entrepreneurial Intentions of University Students: An International Comparison between African, European and Canadian Students}

\section{Introduction}

The importance of entrepreneurship for the economic development of any country is now widely recognized (Thomas and Mueller, 2000). Entrepreneurial activity is linked to job creation (Birch, 1987), economic growth (Acs and Armington, 2003) and innovation (Reynolds et al., 1994). This enthusiasm for entrepreneurship is obviously felt all over the world, in developed countries, but increasingly in developing countries as well. Such is the case in Algeria, a country willing to put into place development policies driven by other industrial sectors than hydrocarbons. To achieve this, several initiatives have been taken to encourage and fund youth business start-ups. However, given the lack of studies on this subject, it is difficult to measure the impact of these start-up support measures, particularly among university students, for whom this issue is important since among a total unemployment rate of $10 \%$, university graduates are the most affected at $21.4 \%$ (ONS, 2010).

Although the situation has improved, Algeria continues to suffer from a high unemployment rate, particularly among young people. Since the institutional reforms of 1989, the government has tried to re-establish a macro-economic balance as a way out of the generalized crisis of the 1990s, before implementing new employment policies, dissociating itself from the "socialist economy". As a result, the unemployment rate dropped substantially from 2003 to 2010. Although these numbers are reassuring, the demographic specificity of Algeria tells a different story. The results of the 2010 study reveal a significant disparity based on age, gender and level of education. Youth unemployment (age 16-24) reached 21.5\%, whereas the adult rate (age 25 or older) was $7.1 \%$ (ONS, 2010). Youth represented $43.2 \%$ of all unemployed workers and over $25 \%$ of young people aged 15 to 24 are neither educated, nor integrated into the labour market. $72 \%$ of job seekers are younger than 30 . Unemployment particularly affects university students, and especially graduate students, who represent $21.4 \%$ (11.1\% men and $33.6 \%$ women) of all students, whereas the unemployment rate among those without university education was estimated at $7.3 \%$. Out of the 120,000 students who graduate from Algerian universities every year, 50,000 are unable to find work. Since 2000, the government has designed several programs to stimulate entrepreneurship among young people. Entrepreneurship is thus part of the Algerian restructuring strategies. It cannot be dissociated from the national cultural and sociopolitical aspects that affect the behaviour of entrepreneurs.

Few studies have explored entrepreneurship in Algeria. The country has been a part of the Global Entrepreneurship Monitor since 2011 and was part of the GEM-MENA ${ }^{3}$ in 2009, but data remain scarce. These data show that among the countries of the MENA region, Algeria has one of the lowest rates of adult entrepreneurial activity, but that those who want to become entrepreneurs are opportunity-motivated (rather than necessity-motivated). However, there are currently no data regarding the situation of youth entrepreneurship in

\footnotetext{
${ }^{3}$ Middle-East and North Africa (MENA)
} 
Algeria. Among the research on Algerian entrepreneurship, we find studies on the entrepreneurial profile (Hammouda and Lassassi, 2006; Leghima and Meguelti, 2006) and on motivations of young Algerians to start businesses (Bensedik, 2010). In the latter, the authors stress that young Algerian entrepreneurs consider starting a business as an alternative to school-to-work transition and as a way to reach social achievement, which suggests that Algerian entrepreneurship should be seen as necessity driven among the youth. In addition, according to Ziane and Ziane (2006), product or service innovation remains rather scarce among Algerian entrepreneurs, who rather tend to focus their efforts on modifying or improving products or creating new processes. Despite these few studies on Algerian entrepreneurship, entrepreneurial intentions, in particular those of university students, have been the subject of very little research (Benredjem, 2009).

Given Algeria's current context and taking into account the objectives set by the government to promote entrepreneurship (1 million businesses created in 2025), to compensate its dependence on oil, evaluating the entrepreneurial intentions of university students and comparing these with results from other continents could be quite important for two reasons. Firstly, although an increasing number of studies on the entrepreneurial intentions of university students have been carried out in recent years (e.g. Nabi et al., 2010; Wilson et al., 2007; Zellweger et al., 2011; Zhao et al., 2005), the focus is most often placed on North American or European samples, whereas other continents, such as Africa, remain unexplored. Secondly, this knowledge is of primary importance since it may open the way public policies better suited to university students who want to create their businesses and thus, support the Algerian government in its objective to foster entrepreneurship and to reduce the youth unemployment. Further studies could lead to a better understanding of the supply and demand conditions that encourage entrepreneurial activity in various regions around the globe (Thomas and Mueller, 2000), especially among young people. Are entrepreneurial characteristics universal, or do they vary on the basis of culture? And, more specifically, are the factors that determine entrepreneurial intentions similar from one country to another? Few studies have answered these questions, in particular with respect to samples of younger people.

This study therefore aims to compare the entrepreneurial intentions of Algerian university students with those from North America (Canada) and Europe (France and Belgium), and to highlight differences with regard to psychological, sociocultural and economic factors that could influence such intentions. The rest of this paper proceeds as follows: we will first summarize the entrepreneurial intentions literature, then the one on cultural differences in entrepreneurial intentions. Our hypotheses will be developed in the latter. After having presented our methodology, our results will be discussed and suggestions for future research avenues and more appropriate public policies for youth entrepreneurship in Algeria will be made.

\section{The entrepreneurial intentions literature}

The theoretical approach to entrepreneurial intention is essentially based on two theories: Shapero and Sokol's entrepreneurial event model (1982) and Ajzen's theory of planned behaviour (TPB) (1991). According to Shapero and Sokol's (1982) entrepreneurial event 
model, an individual makes a decision to start a business on the basis of three elements: 1) his perception of the desirability of the behaviour; 2) his propensity to act, i.e. the willingness to act according to his intentions and 3) his perception of the feasibility of the behaviour under consideration. Many studies have used this model in an attempt to understand entrepreneurial behaviour (Davidsson, 1995; Krueger, 1993; Krueger and Brazeal, 1994; Krueger and Carsrud, 1993; Krueger et al., 2000; Reitan, 1996). According to Shapero and Sokol (1982), the entrepreneurial behaviour is directly influenced by perceptions of desirability and feasibility of the behaviour; the desirability and feasibility both being a reflection of the individual's beliefs and perceptions of the world around him. Thus, the perceived desirability and feasibility, and the resulting intention to start a business, are based on an individual's beliefs. More specifically, the perception of desirability refers to the appeal of starting one's own business (Shapero and Sokol, 1982). This perception is, in particular, influenced by models in the individual's environment (Audet, 2004). Furthermore, cultural and social factors directly affect the perceived desirability of an entrepreneurial behaviour. Social pressure, for example, translates into professional characteristics that are conveyed and highly valued. As indicated by Gasse and Tremblay (2007), intentions are influenced by the perception that entrepreneurial behaviour is personally desirable and, then, socially desirable as well. In addition to being desirable, the act of starting a business must also be reasonably feasible, or at least perceived as such. Feasibility thus refers to the degree to which an individual believes he can successfully create a business. It depends, for example, on the perceived availability of resources deemed necessary to start the business, as well as the skills and confidence of the entrepreneur to successfully carry out the tasks he believes are critical to a successful entrepreneurial process.

The theory of planned behaviour (TPB) is an extension of the theory of reasoned action proposed by Ajzen and Fischbein (1980). The central element of the theory of planned behaviour is the concept of intention. This author suggests that intention reflects the intensity with which an individual is prepared to attempt, and the amount of effort he plans to invest, to adopt a behaviour (Ajzen, 1991). Thus, the greater the intention to adopt a behaviour, the more concrete the behaviour will become. According to the TPB, intention predicts behaviour via three variables. The first variable is the set of attitudes associated with the behaviour. This reflects the assessment by the individual of the desired or contemplated behaviour. These attitudes vary according to the anticipated results and consequences of the behaviour in question. These attitudes recall the concept of desirability put forward by Shapero and Sokol (1982). The second variable is subjective norms, which reflect the social pressure felt by the individual. These include, for example, the career aspirations for the individual held by family and friends. The social norms proposed in Ajzen's model (1991) are also included in Shapero and Sokol's concept of desirability (1982). The third variable is the perceived behavioural control. This variable is the most significant update from the model of reasoned action. According to Ajzen (1991), in order to adopt a behaviour or to intend to do so, an individual must believe that he can control and master the necessary resources and skills to adopt the behaviour in question. Perceptions of behavioural control share common elements with the Shapero and Sokol's concept of feasibility (1982). 
Both models have a lot in common. These similarities have been highlighted by Krueger and Brazeal (1994) and Krueger et al. (2000) who suggest that, in the case of a planned behaviour such as creating a business, the intention precedes the action and is an excellent indicator of that action being carried out. The results of a study by Kolvereid (1996) demonstrate the usefulness of the TPB. Furthermore, it appears that it is easier to explain long-term rather than short-term intentions. For example, the results reported by Reitan (1996) only explain $30 \%$ of the variance when the dependent variable is the intention of becoming an entrepreneur in the two following years (compared to $63 \%$ for the long-term intention). Similar results reported by Audet (2004) explain 32\% of the variance of shortterm intention ( $<3$ years), compared to $49 \%$ for the long term.

Despite the interest of intention-based models to explain behaviours, these are not without limitations. As Boissin and Emin (2006) have suggested, research based on these models are limited to explaining intentions and, as a result, ignore the actual execution of the action. In addition, Moreau and Raveleau (2006) raise the lack of flexibility of the model where the stability of the entrepreneurial intention has not been proven. Nevertheless, intention-based models have been tested on numerous occasions with satisfactory results. In this context, to compare the various factors that influence university students' entrepreneurial intentions, we use Ajzen's model of planned behaviour (1991), which has been widely used in the entrepreneurial literature (Fitzsimmons and Douglas, 2011; Krueger and Carsrud, 1993; Krueger et al., 2000; Van Gelderen et al., 2008).

\section{International comparisons of entrepreneurial intention}

In a study on Russian students, Tkackev and Kolvereid (1999) show that the TPB explains $45 \%$ of the variance of entrepreneurial intention and that socio-demographic factors are not significant. A similar research conducted with South African students shows TPB's usefulness as it explains $27 \%$ of the variance of entrepreneurial intention (Gird and Bagraim, 2008). However, in a sample of Chinese students, it appears that subjective norms are not significant in explaining entrepreneurial intention while attitudes and perceived behavioural control are (Wu and $\mathrm{Wu}, 2008)$. These results are also similar to those obtained with samples of Spanish students from two regions of Spain (Liñán et al., 2011) and with a sample of Taiwanese students (Liñán and Chen, 2009). A study conducted in six culturally very different countries (Germany, India, Iran, Poland, Spain, and the Netherlands) also confirms that subjective norms in certain countries do not explain entrepreneurial intention (Moriano et al., 2012). Furthermore, Kolvereid and Isaksen's (2006) study reveals the absence of a significant impact of attitude toward the behavior when trying to explain Norwegians entrepreneurial intention. The attitude toward the behavior also varies considerably among different countries when investigated with samples of students (Giacomin et al., 2011).

Those results suggest that certain cultural, socioeconomic or political factors could modify the influence of the components of TPB when explaining entrepreneurial intention, especially subjective norms and attitudes. In addition, recent international comparisons show that TPB's explanatory power varies greatly from one country to another (Engle et al., 2010), with an adjusted $R^{2}$ fluctuating between 0.09 in Egypt and 0.42 in the United 
States and Spain. Furthermore, as said earlier, this study confirms that certain variables in our model are not significant in certain contexts while they are in others. We could this assume that the three antecedent variables of intention are important but that the cultural context or the country can modulate their importance.

Moreover, some scholars contend that theories conceived and tested in economically developed countries are used on a large scale in countries with emerging economies without any efforts of adaptation (Bruton et al., 2008). They suggest that the sometimes important differences among countries require adapting or proposing new and more useful theories for those different environments. From this point of view, TPB was conceptualized for out and mostly used with samples from developed countries. Using TPB in the Algerian setting could thus lead to a weaker explanatory power. For example, the only study using a North African sample somehow similar to Algeria shows that, out of twelve countries studied, Egypt has the lowest explanatory power (Engle et al., 2010). Even though a recent international study by Iakovleva et al. (2011) reveals little differences among countries in terms of explatory power, we believe that differences could exist in the particular situation of North Africa. This leads us to propose the following hypothesis:

H1: TPB will have a weaker explanatory power in Algeria than in Europe or Canada.

It is well known that national cultures influence their citizens' entrepreneurial intention (Pruett et al., 2009). GEM's data indicate that Algerians' attitudes and feelings of entrepreneurial self-efficacy are among the weakest within MENA countries (GEM, 2009). Furthermore, Algerians are the most numerous to believe that entrepreneurship is not a desirable career choice and they also have the lowest prevalence rate in total entrepreneurship activity among all adults surveyed, particularly in entrepreneurial intention. In contrast, these rates are much higher than those in industrialized countries, particularly France and Belgium (GEM, 2009). It is thus probable that entrepreneurial intention as well as TPB'S main explaining factors could be higher among Algerian students when compared to Canadians or Europeans. Consequently we propose the following hypotheses:

H2: Algerians students' entrepreneurial intention will be higher than European or Canadian students' ones.

H3: Attitude toward action, Perceived behavioural control and Subjective norms will be higher among Algerian students than among European and Canadian students.

\section{Methodology}

This section describes the sample used to test our hypotheses. A presentation of the measures used for the various concepts and the analysis conducted will follow.

\section{Sample}

The sample used in this study was drawn from an extensive investigation on entrepreneurial careers. The main objective of this investigation was to understand the factors that determine the entrepreneurial intentions of students as well as their actions, seen through 
social cognitive career theory (Lent et al., 2002). In total, students from 13 universities were contacted to answer a questionnaire: Ten Canadian universities, one French business school, one Belgian university and one Algerian university. The invitation was sent by email or posted on student Intranets or institutional newspapers. A total of 1,810 students agreed to take part in this first phase of the five-year annual investigation. This is a nonprobabilistic sample.

Most respondents studied in Canada (64\%), then Belgium (18.5\%), France $(9.5 \%)$ and Algeria (8\%). Although they were from different university departments, except for the French students, they were mostly registered in management sciences $(37.5 \%)$, pure sciences and engineering (25.5\%), human and social sciences $(9.9 \%)$ and distributed among other disciplines. The students were mostly at the undergraduate level $(55.4 \%)$ and, to a lesser degree, the master's level $(39.6 \%)$ or doctoral level $(5 \%)$. For the purposes of this investigation, we grouped the French and Belgian students together so as to have three groups: Canada, Europe and Algeria.

The sample was $48.7 \%$ male (51.3\% female), whose ages ranged from 17 to 69 , with an average age of 25.19 (median 23) and a standard deviation of 6.42. They had relatively little full-time work experience, with an average of 3.37 years (median 2) and a standard deviation of 3.42. The same situation applies to full-time work experience as a supervisor or manager, with an average of 1.93 years (median 1) and a standard deviation of 2.20. This is perfectly normal since they were university students. The sample mostly included Caucasian students (84.4\%), followed by students of Arabic (8\%), African (4.1\%) descent and others $(3.5 \%)$. A total of $45.6 \%$ of the sample had parents who had been, or were currently, in business, and only $7.2 \%$ had been in business in the past.

\section{Measures}

Entrepreneurial intention was measured with six (6) items using a 7 point Likert scale (ex. I'm saving up money to start a new business) and was a French translation of the measure developed by Thompson (2009). The measure is unidimensional $(61.3 \%$ of the variance explained by the exploratory factorial analysis) with a Cronbach's Alpha of 0.867 . We used the average score of the six items for this study.

The strength of the aspiration to an identity as an entrepreneur was measured with five (5) items using a 7 point Likert scale (ex. I would like to see myself as an entrepreneur) and was a French translation of the measure used by Farmer et al. (2009). The measure is unidimensional (87.4\% of the variance explained) with a Cronbach's Alpha of 0.964 . We used the average score of the five items for this study.

The clarity of entrepreneurial goals was measured with eight (8) items using a 7 point Likert scale (ex. I have a set of clear goals for my future as an entrepreneur) and was an adaptation and French translation of the measure used by Rogers et al. (2008). The measure was unidimensional (71.7\% of the variance explained) with a Cronbach's Alpha of 0.942 . We used the average score of the eight items for this study. 
The attitude toward action was measured with (5) items using a 7 point Likert scale based on the proposal by Krueger (2000). This author identified four expectations with regard to entrepreneurship which could motivate an individual to start a business. This includes financial reward, independence/autonomy, personal rewards (i.e. to prove to myself that I can do it) and family security (i.e. to build a transferable business). We added "to improve society" in order to account for social entrepreneurs (Zahra et al., 2009). Cronbach's Alpha was 0.60 . We used the average score of the five items for this study.

The perceived behavioural control corresponded to the twenty (20) items of the selfefficacy measure developed by McGee et al. (2009). The scale is calibrated from $0 \%$ to $100 \%$ with regard to the individual's perception of self-efficacy on these questions. The measure was developed taking into account five sub-dimensions of entrepreneurial selfefficacy, that is, opportunity recognition, planning, vision, conceptual and human competencies and financial competencies. Cronbach's Alpha was 0.918 and the scale ranges from 0 to 10 . We used the average score of the twenty items for this study.

The measure of subjective norms included twelve (12) items using a 7 point Likert scale. It was developed by Kolvereid and Isaksen (2006) and included two components, that is, the opinions of six groups that surround the individual (parents, spouse, sibling, relatives, close friends and acquaintances) about an entrepreneurial career, and the importance the individual gives to the opinions of each of these groups. Opinions were recoded from -3 to +3 and multiplied by the importance given, with a combined measure going from -21 to +21 for each item. Cronbach's Alpha was 0.809 . We used the average score of the six groups for this study.

\section{Results}

Tables 1, 2 and 3 show the means, standard-deviations and intercorrelations for all the variables used in this study for the Canadian, European, and Algerian samples, respectively.

Table 1. Descriptive statistics and intercorrelations ${ }^{\mathrm{d}}$ for all variables - Canadian sample $\left(\mathrm{n} \geq 761^{\mathrm{e}}\right)$

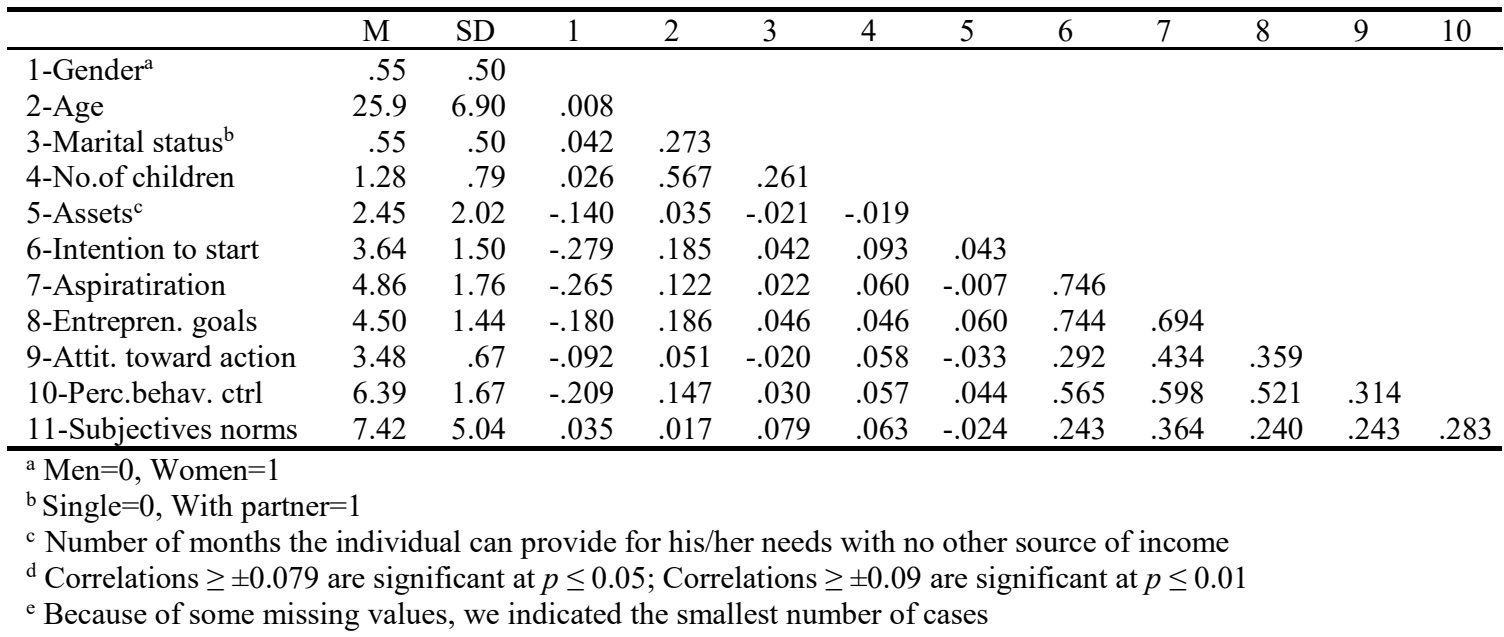


Table 2. Descriptive statistics and intercorrelations ${ }^{\mathrm{d}}$ for all variables - European sample $\left(\mathrm{n} \geq 278^{\mathrm{e}}\right)$

\begin{tabular}{|c|c|c|c|c|c|c|c|c|c|c|c|c|}
\hline & $\mathrm{M}$ & SD & 1 & 2 & 3 & 4 & 5 & 6 & 7 & 8 & 9 & 10 \\
\hline 1-Gender ${ }^{\mathrm{a}}$ & .46 & .50 & & & & & & & & & & \\
\hline 2-Age & 22.7 & 3.93 & .082 & & & & & & & & & \\
\hline 3-Marital status ${ }^{\mathrm{b}}$ & .28 & .45 & .132 & .195 & & & & & & & & \\
\hline 4-No.of children & .61 & .61 & .123 & .205 & .113 & & & & & & & \\
\hline 5-Assets ${ }^{\mathrm{c}}$ & 2.42 & 2.37 & -.059 & .120 & .029 & .080 & & & & & & \\
\hline 6-Intention to start & 3.39 & 1.54 & -.255 & .142 & .010 & -.334 & .098 & & & & & \\
\hline 7-Aspiratiration & 4.38 & 1.87 & -.301 & .135 & .036 & -.294 & .069 & .713 & & & & \\
\hline 8-Entrepren. goals & 4.32 & 1.48 & -.133 & .161 & .130 & -.142 & .139 & .723 & .662 & & & \\
\hline 9-Attit. Toward action & 3.69 & .63 & -.049 & -.064 & -.040 & -.280 & .001 & 268 & .284 & .346 & & \\
\hline 10-Perc.behav. ctrl & 5.68 & 1.72 & -.221 & .101 & -.008 & -.185 & .122 & .470 & .587 & .410 & .171 & \\
\hline 11-Subjectives norms & 6.77 & 5.32 & -.010 & .045 & .057 & -.237 & .101 & .340 & .381 & .220 & .246 & .283 \\
\hline
\end{tabular}

a Men $=0$, Women $=1$

${ }^{\mathrm{b}}$ Single $=0$, With partner $=1$

${ }^{\mathrm{c}}$ Number of months the individual can provide for his/her needs with no other source of income

${ }^{\mathrm{d}}$ Correlations $\geq \pm 0.101$ are significant at $\mathrm{p} \leq 0.05$; Correlations $\geq \pm 0.132$ are significant at $\mathrm{p} \leq 0.01$

e Because of some missing values, we indicated the smallest number of cases

Table 3. Descriptive statistics and intercorrelations ${ }^{\mathrm{d}}$ for all variables - Algerian sample $\left(\mathrm{n} \geq 79^{\mathrm{e}}\right)$

\begin{tabular}{|c|c|c|c|c|c|c|c|c|c|c|c|c|}
\hline & M & SD & 1 & 2 & 3 & 4 & 5 & 6 & 7 & 8 & 9 & 10 \\
\hline 1-Gender ${ }^{\mathrm{a}}$ & .43 & .50 & & & & & & & & & & \\
\hline 2-Age & 27.8 & 6.65 & -.094 & & & & & & & & & \\
\hline 3-Marital status ${ }^{\mathrm{b}}$ & .31 & .47 & -.153 & .482 & & & & & & & & \\
\hline 4-No.of children & 1.26 & .64 & -.076 & .649 & .511 & & & & & & & \\
\hline 5-Assets ${ }^{c}$ & 3.38 & 2.83 & -.108 & .157 & .025 & .096 & & & & & & \\
\hline 6-Intention to start & 4.68 & 1.14 & -.226 & .003 & .003 & -.116 & .014 & & & & & \\
\hline 7-Aspiratiration & 5.75 & 1.16 & -.147 & .178 & .247 & .167 & .082 & .405 & & & & \\
\hline 8-Entrepren. goals & 5.46 & 1.05 & -.229 & .132 & .041 & .043 & -.100 & .572 & 477 & & & \\
\hline 9-Attit. Toward action & 3.89 & .74 & -.180 & .021 & .059 & -.019 & -.081 & .146 & .302 & .286 & & \\
\hline 10-Perc.behav. ctrl & 6.91 & 1.42 & -.067 & .039 & -.014 & -.122 & .171 & .212 & .283 & .120 & .278 & \\
\hline 11-Subjectives norms & 9.04 & 5.73 & .056 & -.054 & -.075 & .091 & .066 & .074 & .138 & .129 & .131 & .110 \\
\hline
\end{tabular}

${ }^{\mathrm{a}} \mathrm{Men}=0$, Women $=1$

${ }^{\mathrm{b}}$ Single $=0$, With partner $=1$

${ }^{\mathrm{c}}$ Number of months the individual can provide for his/her needs with no other source of income

${ }^{\mathrm{d}}$ Correlations $\geq \pm 0.180$ are significant at $\mathrm{p} \leq 0.05$; Correlations $\geq \pm 0.229$ are significant at $\mathrm{p} \leq 0.01$

${ }^{\mathrm{e}}$ Because of some missing values, we indicated the smallest number of cases

We compared the different populations on the basis of entrepreneurial intention, the strength of the aspiration to an identity as an entrepreneur, clarity of entrepreneurial goals, attitude toward action, perceived behavioural control and subjective norms. As illustrated in Table 4, entrepreneurial intentions are higher among Algerian than Canadian or European students, and higher among Canadian than European students. This confirms H1. The same phenomenon was noted with regard to the strength of the aspiration to an identity as an entrepreneur and perceived behavioural control. 
Table 4. Comparison of Indicators by Continent

\begin{tabular}{llll}
\hline & Canada & Europe & Algeria \\
\hline Entrepreneurial intention & $3.635^{\mathrm{ab}}$ & $3.394^{\mathrm{ac}}$ & $4.685^{\mathrm{bc}}$ \\
Strength of aspiration to an entr. identity & $4.864^{\mathrm{ab}}$ & $4.376^{\mathrm{ac}}$ & $5.747^{\mathrm{bc}}$ \\
Clarity of entrepreneurial goals & $4.496^{\mathrm{a}}$ & $4.315^{\mathrm{b}}$ & $5.456^{\mathrm{ab}}$ \\
Attitude toward action & $3.478^{\mathrm{ab}}$ & $3.687^{\mathrm{ac}}$ & $3.891^{\mathrm{bc}}$ \\
Perceived behavioural control & $6.390^{\mathrm{ab}}$ & $5.679^{\mathrm{a}}$ & $6.905^{\mathrm{b}}$ \\
Subjective norms & $7.424^{\mathrm{a}}$ & $6.775^{\mathrm{b}}$ & $9.042^{\mathrm{ab}}$ \\
\hline
\end{tabular}

$\mathrm{a}, \mathrm{b}$ and $\mathrm{c} A$ difference of $p \leq 0.05$ between two groups is indicated by a, b, and c. Tamhane's post-hoc

test for unequal variances was used

However, clarity of entrepreneurial goals is higher among Algerian students when compared to Canadians and Europeans, but no significant difference was observed between the Canadians or Europeans. Attitude toward action was again highest among Algerians (compared to Canadians and Europeans), and this indicator was higher among Europeans than Canadians. Lastly, subjective norms were higher among Algerians than Canadians or Europeans, with no significant difference between the latter two groups. These findings confirm $\mathrm{H} 2$.

With respect to factors that could explain entrepreneurial intentions, Table 5 (Model 2) shows that men have higher entrepreneurial intentions and that age also has a positive effect on intention. In addition, the number of children under one's care has a significant negative effect. As the theoretical model would suggest, attitude toward action, perceived behavioural control and subjective norms all have a significant and positive effect on entrepreneurial intentions. 
Table 5

Entrepreneurial Intention Regression (all students)

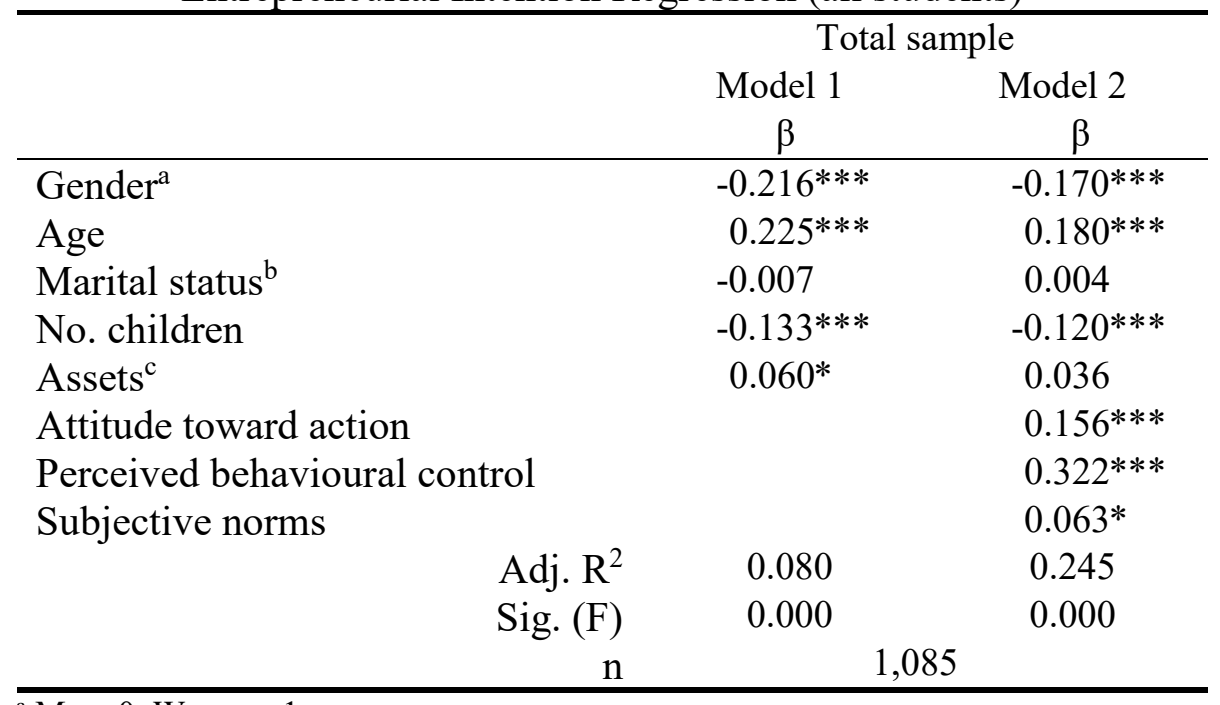

${ }^{\text {a } M e n=0, ~ W o m e n=1 ~}$

${ }^{\mathrm{b}}$ Single $=0$, With partner $=1$

${ }^{c}$ Number of months the individual can provide for his/her needs with no other source of income

$\dagger=p \leq 0,10 ; *=p \leq 0,05, * *=p \leq 0,01 ; * * *=p \leq 0,001 ;$

The picture changes radically when the samples are divided by continent. As illustrated in Table 6, the Algerian student group shows no significant variable to explain entrepreneurial intentions (Model 2). The explanatory power of the Algerian students' sample (0.020) is lower than the one of the Canadian (0.279) and European (0.181) samples. This confirms H3. 
Table 6

Entrepreneurial Intention by Continent Regression

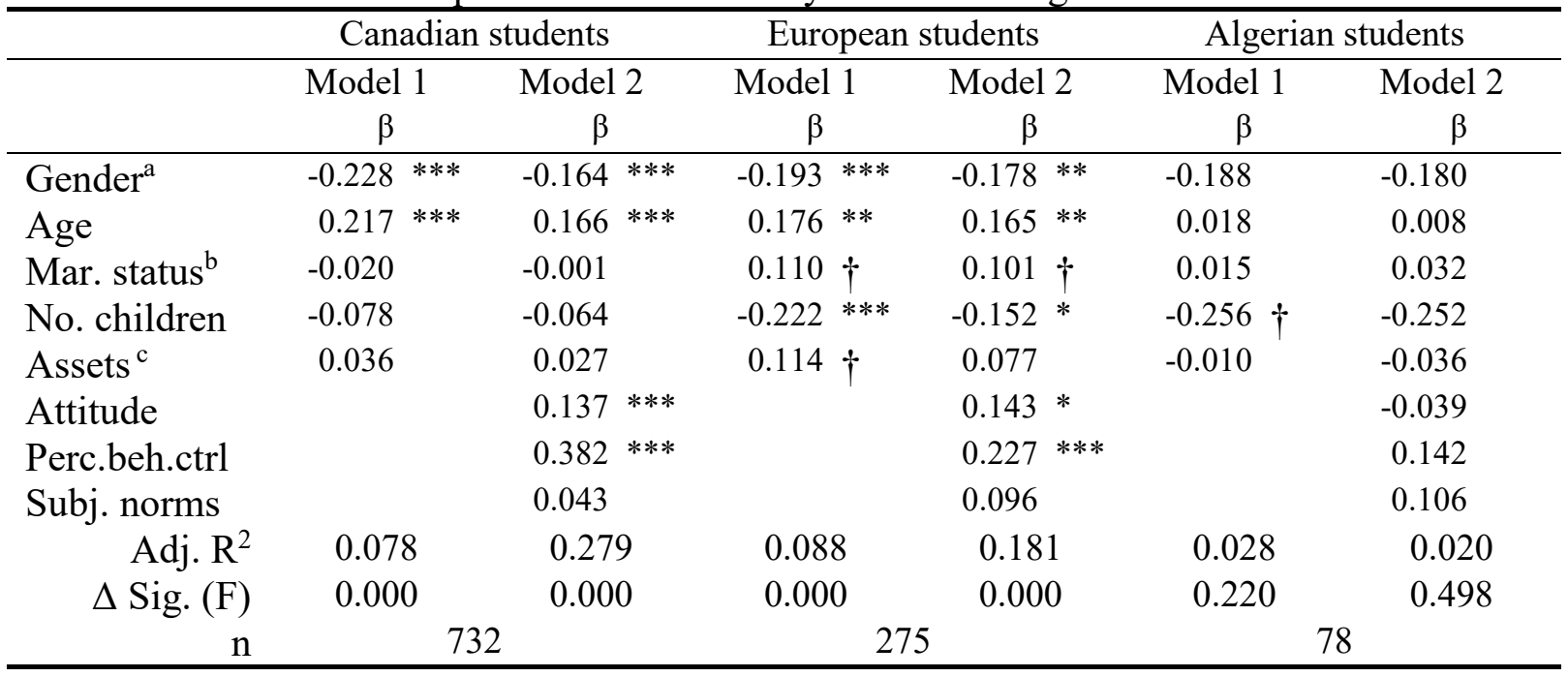

${ }^{\mathrm{a}}$ Men $=0$, Women $=1$

${ }^{\mathrm{b}}$ Single $=0$, With partner $=1$

${ }^{\mathrm{c}}$ Number of months the individual can provide for his/her needs with no other source of income

$\dagger=p \leq 0.10 ; *=p \leq 0.05, * *=p \leq 0.01 ; * * *=p \leq 0.001$;

\section{Discussion}

The results are interesting in several respects. First, we note that all entrepreneurial intention indicators are higher among Algerian students than students from Western countries. This can be explained in two ways. First, the economic situation in which university students find themselves can certainly motivate them to start a business in order to earn a living and fulfill their potential. Second, the numerous incentives put forward by the Algerian Government to support business start-ups among this particular group may also influence the results and lead to these marked differences. From the GEM-MENA study, we knew that entrepreneurial activities and attitudes among the adult population were the lowest of the MENA region (GEM, 2009). Our study confirms that, when compared with industrialized countries or other regions of the world, the picture is quite nuanced and suggests that Algerian university students are interested in entrepreneurship, that they perceive themselves as capable of engaging in entrepreneurial activities and that they sense the support to do so from their entourage.

The analyses conducted with on the whole sample confirm the relevancy of the theory of planned behaviour (TPB) proposed by Ajzen (1991). Indeed, attitudes, perceived behavioural control and subjective norms are all significant and explain $16.5 \%$ of the variance, once controlled for other factors related to entrepreneurial intentions, such as gender, age and number of children under one's care. Thus, men and older individuals with fewer children under their care are more likely to intend to start a business.

The results are particularly interesting once the analyses are conducted according to cultural group. As noted earlier, the analysis for Canadian and European students show little differences with regard to the significant variables, even if the contribution of the TPB to explain entrepreneurial intentions represents $20.1 \%$ of the variance for the Canadians 
and $9.3 \%$ for the Europeans. However, no TPB element was significant for the Algerian students, at least no more than the control variables. At first glance, one could suspect that this may be due to the small number of respondents (78), which would reduce the power of the regression. However, if we estimate a similar size effect for the European students $\left(R^{2}=0.181\right)$ with a sample of 78 , the regression model used has a power of 0.882 , which is more than sufficient to find any existing significant relationships. Those results are consistent with Shook and Bratiany (2010), who tested Ajzen's model (1991) with a culturally diverse group of students, and obtained divergent results, showing that the entrepreneurial intentions of Romanian students were negatively influenced by subjective norms, whereas the effect was positive in other countries. This also confirms that studying North African students, and maybe the whole population, may require specific variables to better explain their entrepreneurial intentions, since we have very low explanatory power (0.020), just as it was the case for an Egyptian sample (Engle et al., 2010). This could mean that our understanding of entrepreneurship and of entrepreneurial intentions cannot solely be based on the economic and social environments. Other cultural factors could explain this phenomenon and a more inductive approach might be helpful in order to develop a theory that would be better suited for specific economic and cultural contexts (Bruton et al., 2008).

Many authors have underestimated the importance of cultural influence on economic behaviour (Kombou and Saporta, 2000; Landes, 1998). Various beliefs held by individuals, in particular with regard to entrepreneurship, are influenced by culture and social context (Arenius and Minniti, 2005; Shinnar et al., 2012). For example, certain cultures place a higher value on financial success and business activities (McClelland, 1967). In their study, Ulhaner et al. (2002) noted that countries whose culture may be qualified as postmaterialistic show a lower rate of entrepreneurial activity. One study on the significance of the impact of national culture on the behaviours of entrepreneurs (Tounés and Assala, 2007) revealed strong cultural values such as collectivism, femininity and the absence of entrepreneurial vision which characterized the managerial behaviours of entrepreneurs. In their conclusion, the authors stated the following: "The repercussions of the impact of culture on behaviours and, in turn, on managerial practices can be seen at various levels of a business, in particular, with regard to the management of human resources, management of information and the entrepreneurial vision" [our translation](Tounés and Assala, 2007, p. 23). Although it is reasonable to assume that the macroeconomic environments of some countries favour entrepreneurial behaviours whereas others may hinder them, the relationship between cultural and intercultural indicators and entrepreneurial behaviours is complex and requires further research (Arenius and Minniti, 2005). This may be an important path to explore in order to better understand the entrepreneurial intentions' process of Algerians, or of inhabitants of other North African countries, in future researches.

Our results seem to show that the theory of planned behaviour could not be applied in the same manner in the Algerian context as in the other countries, or that it does not have the same effect. If we recognize the fact that the effect of size was much smaller than for the two other groups under study, to the extent that no relationship appears significant for a sample of that size, this would mean that increasing the size of the sample would result in 
significant relationships, but with a much smaller $R^{2}$ than for the other groups (Canadian and European). It therefore appears that the TPB, which focuses on an individual and not his/her environment, is of little use to understand the entrepreneurial intentions of Algerian students. The TPB includes three components: attitudes, perceived behavioural control and subjective norms. It is obvious that the first two components are related to the individual and not the environment. As for the subjective norms, even though respondents must consider the opinions of others in their surroundings with regard to an eventual career as an entrepreneur, this is moderated by the importance the individual attributes to these opinions, and this assessment depends on the individual's perceptions. In other words, even the subjective norms component, which is rooted in external elements, is evaluated through the eyes of the individual. In the context of Algeria, given the socioeconomic situation of university students and the business start-up measures implemented by the Government, it would be reasonable to suggest that entrepreneurial intentions could be primarily influenced by external elements, which are not accounted for by the TPB. It could also be suggested that Algerian students are motivated by necessity rather than opportunity. This type of entrepreneurship mainly generated by youth unemployment situation in that country, is likely to diminish the level of satisfaction of being an entrepreneur, given the strong influence of external elements (rather than intrinsic motivators) in the career choice decision-making process (Block and Koellinger, 2009). However, the GEM-MENA study shows that entrepreneurial activity at large in Algeria is more opportunity-driven than necessity-driven (GEM, 2009). In the light of our results, it seems that age may act as moderator, where younger people may be more necessity-driven than the older individuals, given their high unemployment rate. This potential explanation would require further analysis in future studies.

\section{Limitations and future research directions}

This study has several limitations. First, it is important to stress that the sample was not probabilistic and that the students who participated in the investigation cannot be considered as representative of the total population of university students. It is likely that students with an interest in an entrepreneurial career responded more massively than other students, out of personal interest, which would inflate the levels of entrepreneurial intentions and other related indicators. It is impossible to determine whether the appeal to respond was stronger for certain cultures or student sub-groups. Comparisons of averages must be interpreted by taking this fact into account. In addition, we used aggregate measures with regard to the three main components of the TPB. For example, the five dimensions of entrepreneurial self-efficacy (ESE) were averaged out to represent a measure of perceived behavioural control. Any small gains were counterbalanced by losses in detailed analyses, since we cannot assess the specific effect of each of these dimensions on entrepreneurial intentions. We should add that perceived behavioural control is typically measured in such a way as to assess both internal control, like we did with the use of an ESE measure, and external control, something that is currently lacking in our analysis.

This suggests several avenues for future research. First, it would be useful to compare other countries with similar socioeconomic conditions as Algeria, such as the other Maghreb countries, some Eastern European countries, or even countries on other continents such as Asia or South America. Furthermore, given the possibility that entrepreneurial activity in 
Algeria would be necessity-driven, which is likely to lead to less entrepreneurial satisfaction, it would be important to conduct further research from a longitudinal perspective in order to study the elements that are likely to lead to business creation by Algerian students (or from other cultures) and to compare the types of businesses that are created in the different countries. Lastly, we believe that future research should include considerations related to economic conditions in any analysis of entrepreneurial intentions. As a result, these theories could be used to study youth living in industrialized countries as well as the developing world.

\section{References}

Acs, Z.J. and Armington, C. (2003), "Endogenous growth and entrepreneurial activity in cities", Discussion paper CES 03-02, Center for Economic Studies, Bureau of the Census, Washington, DC.

Ait Ziane, K. and Ait Ziane, H. (2006) 'Territoire et entrepreneur innovateurs : cas de l'Algérie', Paper presented at the Colloque international de la création d'entreprise et territoires 3-4 décembre, Tamanrasset (Algérie).

Ajzen, I. (1991) 'The theory of planned behavior', Organizational Behavior and Human Decision Processes, Vol. 50 No. 2, pp. 179-211.

Ajzen, I. and Fishbein, M. (1980) Understanding attitudes and predicting social behavior (Vol. 278), Prentice-Hall, Engle-Wood-Cliffs, NY.

Arenius, P. and Minniti, M. (2005) 'Perceptual Variables and Nascent Entrepreneurship', Small Business Economics, Vol. 24 No. 3, pp. 233-247.

Audet, J. (2004) 'L'impact de deux projets de session sur les perceptions et intentions entrepreneuriales d'étudiants en administration', Journal of Small Business and Entrepreneurship, Vol. 17 No. 3, pp. 223-240.

Benredjem, R. (2009), "L'influence entrepreneuriale: l'influence des facteurs liés à l'individu et au milieu", Cahiers de recherche du CERAG, CERAG.

Bensedik, A. (2010), "Les caractéristiques psychologiques chez les jeunes entrepreneurs", Cahiers de recherche du CREAD No. 90, CREAD.

Birch, D.L. (1987) Job Creation in America, Free Press, New York.

Block, J. and Koellinger, P. (2009) 'I can't get no satisfaction-Necessity entrepreneurship and procedural utility', Kyklos, Vol. 62 No. 2, pp. 191-209.

Boissin, J.-P. and Emin, S. (2006) 'Les étudiants et l'entrepreneuriat : l'effet des formations', Paper presented at the Conférence Internationale de Management Stratégique, Juin, Annecy/Genève.

Bruton, G.D., Ahlstrom, D. and Obloj, K. (2008) 'Entrepreneurship in emerging economies: Where are we today and where should the research go in the future', Entrepreneurship Theory and Practice, Vol. 32 No. 1, pp. 1-14.

Davidsson, P. (1995) 'Determinants of entrepreneurial intentions', Paper presented at the RENT IX Workshop in Entrepreneurship Research, November, $23^{\text {th }}-24^{\text {th }}$, Piacenza, Italia.

Engle, R.L., Dimitriadi, N., Gavidia, J.V., Schlaegel, C., Delanoe, S., Alvarado, I., He, X., Buame, S. and Wolff, B. (2010) 'Entrepreneurial intent: A twelve country evaluation of Ajzen's model of planned behavior', International Journal of Entrepreneurial Behaviour \& Research, Vol. 16 No. 1, pp. 35-57. 
Farmer, S., Yao, X. and Kung Mcintyre, K. (2009) 'The Behavioral Impact of Entrepreneur Identity Aspiration and Prior Entrepreneurial Experience', Entrepreneurship Theory and Practice, Vol. 35 No. 2, pp. 245-273.

Fitzsimmons, J.R. and Douglas, E.J. (2011) 'Interaction between feasibility and desirability in the formation of entrepreneurial intentions', Journal of business venturing, Vol. 26 No. 4, pp. 431-440.

Gasse, Y. and Tremblay, M. (2007) 'L'impact des antécédents sur les perceptions, attitudes et intentions des étudiants collégiaux et universitaires à l'égard de l'entrepreneuriat ', Paper presented at the XI Conférence Internationale de management stratégique, 6-9 juin, Montréal (Canada).

GEM (2009), "Global Entrepreneurship Monitor: MENA 2009 Regional Report", International Development Research Centre, Cairo, Egypt.

Giacomin, O., Janssen, F., Pruett, M., Shinnar, R.S., Llopis, F. and Toney, B. (2011) 'Entrepreneurial intentions, motivations and barriers: Differences among American, Asian and European students', International Entrepreneurship and Management Journal, Vol. 7 No. 2, pp. 219-238.

Gird, A. and Bagraim, J.J. (2008) 'The theory of planned behaviour as predictor of entrepreneurial intent amongst final-year university students', South African Journal of Psychology, Vol. 38 No. 4, pp. 711-724.

Hammouda, N. and Lassassi, M. (2006) 'Essai sur le potentiel entrepreneurial en Algérie', Paper presented at the $14^{\text {ème }}$ conférence sur les institutions et le développement économique, 28-30 décembre, Caire (Égypte).

Iakovleva, T., Kolvereid, L. and Stephan, U. (2011) 'Entrepreneurial intentions in developing and developed countries', Education+ Training, Vol. 53 No. 5, pp. 353370.

Kolvereid, L. (1996) 'Prediction of Employment Status Choice Intentions', Entrepreneurship: Theory and Practice, Vol. 21 No. 1, pp. 47-57.

Kolvereid, L. and Isaksen, E. (2006) 'New business start-up and subsequent entry into selfemployment', Journal of Business Venturing, Vol. 21 No. 6, pp. 866-885.

Kombou, L. and Saporta, B. (2000) L'entrepreneuriat africain : mythe ou réalité ? Édition Histoire d'Entreprendre, EMS, Paris.

Krueger, N.F. (1993) 'The impact of prior entrepreneurial exposure on perceptions of new venture feasibility and desirability', Entrepreneurship: Theory and Practice, Vol. 18 No. 1, pp. 5-21.

Krueger, N.F. (2000) 'The cognitive infrastructure of opportunity emergence', Entrepreneurship: Theory \& Practice, Vol. 24 No. 3, pp. 5-23.

Krueger, N.F. and Brazeal, D.V. (1994) 'Entrepreneurial potential and potential entrepreneurs', Entrepreneurship Theory and Practice, Vol. 18 No. 3, pp. 91-104.

Krueger, N.F. and Carsrud, A.L. (1993) 'Entrepreneurial intentions: applying the theory of planned behaviour', Entrepreneurship \& Regional Development, Vol. 5 No. 4, pp. 315-330.

Krueger, N.F.J., Reilly, M.D. and Carsrud, A.L. (2000) 'Competing models of entrepreneurial intentions', Journal of Business Venturing, Vol. 15 No. 5-6, pp. 411-432.

Landes, D.S. (1998) The Wealth and Poverty of Nations, W.W. Norton \& Company, NewYork, USA. 
Leghima, A. and Meguelti (2006) 'Le profil de l'entrepreneur comme facteur de succès des entreprises nouvellement créées', Paper presented at the Colloque international, création d'entreprises et territoires, 3-4 décembre, Tamanrasset (Algérie).

Lent, R.W., Brown, S.D. and Hackett, G. (2002) 'Social cognitive career theory', in D. Brown (Ed.), Career choice and development, $4^{\text {th }}$ ed., Jossey-Bass, San-Francisco, USA, pp. 255-311.

Liñán, F. and Chen, Y.-W. (2009) 'Development and cross-cultural application of a specific instrument to measure entrepreneurial intentions', Entrepreneurship Theory and Practice, Vol. 33 No. 3, pp. 593-617.

Liñán, F., Urbano, D. and Guerrero, M. (2011) 'Regional variations in entrepreneurial cognitions: Start-up intentions of university students in Spain', Entrepreneurship and Regional Development, Vol. 23 No. 3-4, pp. 187-215.

McClelland, D.C. (1967) Achieving society, Free Press, New-York, USA.

McGee, J., Peterson, M., Mueller, S. and Sequeira, J. (2009) 'Entrepreneurial Self Efficacy: Refining the Measure', Entrepreneurship Theory and Practice, Vol. 33 No. 4, pp. 965-988.

Moreau, R. and Raveleau, B. (2006) 'Les trajectoires de l'intention entrepreneuriale', Revue internationale PME, Vol. 19 No. 2, pp. 102-131.

Moriano, J.A., Gorgievski, M., Laguna, M., Stephan, U. and Zarafshani, K. (2012) 'A cross-cultural approach to understanding entrepreneurial intention', Journal of Career Development, Vol. 39 No. 2, pp. 162-185.

Nabi, G., Holden, R. and Walmsley, A. (2010) 'Entrepreneurial intentions among students: towards a re-focused research agenda', Journal of Small Business and Enterprise Development, Vol. 17 No. 4, pp. 537-551.

ONS (2010), "Activité, Emploi et Chômage", Office National des Statistiques, Alger, Algeria.

Pruett, M., Shinnar, R., Toney, B., Llopis, F. and Fox, J. (2009) 'Explaining entrepreneurial intentions of university students: a cross-cultural study', International Journal of Entrepreneurial Behaviour \& Research, Vol. 15 No. 6, pp. 571-594.

Reitan, B. (1996) 'Entrepreneurial intentions: A combined models approach', Paper presented at the $9^{\text {th }}$ Nordic Small Business Research Conference, May $29^{\text {th }}$-June $3^{\text {rd }}$, Lillehammer, Norway.

Reynolds, P., Storey, D.J. and Westhead, P. (1994) 'Cross-national comparisons of the variation in new firm formation rates', Regional Studies, Vol. 28 No. 4, pp. 443456.

Rogers, M., Creed, P. and Ian Glendon, A. (2008) 'The role of personality in adolescent career planning and exploration: A social cognitive perspective', Journal of Vocational Behavior, Vol. 73 No. 1, pp. 132-142.

Shapero, A. and Sokol, L. (1982) 'The social dimensions of entrepreneurship', in C. Kent, D. Sexton \& K. V. Vesper (Eds.), The Encyclopedia of Entrepreneurship, Prentice Hall, Englewood Cliffs, pp. 72-90.

Shinnar, R.S., Giacomin, O. and Janssen, F. (2012) 'Entrepreneurial perceptions and intentions: The role of gender and culture', Entrepreneurship Theory and Practice, Vol. 36 No. 3, pp. 465-493. 
Shook, C.L. and Bratianu, C. (2010) 'Entrepreneurial intent in a transitional economy: an application of the theory of planned behavior to Romanian students', International Entrepreneurship and Management Journal, Vol. 6 No. 3, pp. 231-247.

Thomas, A.S. and Mueller, S.L. (2000) 'A case for comparative entrepreneurship: Assessing the relevance of culture', Journal of International Business Studies, Vol. 31 No. 2, pp. 287-301.

Thompson, E. (2009) 'Individual entrepreneurial intent: construct clarification and development of an internationally reliable metric', Entrepreneurship Theory and Practice, Vol. 33 No. 3, pp. 669-694.

Tkachev, A. and Kolvereid, L. (1999) 'Self-employment intentions among Russian students', Entrepreneurship \& Regional Development, Vol. 11 No. 3, pp. 269-280.

Tounés, A. and Assala, K. (2007) 'L'Influences culturelles sur des comportements managériaux d'entrepreneurs algériens', Paper presented at the $5^{\text {ème }}$ Congrès de l'Académie de l'Entrepreneuriat, 4-5 octobre, Sherbrooke (Canada).

Ulhaner, L., Thurik, R. and Hutjes, J. (2002) 'Post-Materialism : a cultural factor influencing self-employment across nations', Paper presented at the Frontiers of Entrepreneurship Research - Babson Conference, Babson College, MA.

Van Gelderen, M., Brand, M., van Praag, M., Bodewes, W., Poutsma, E. and van Gils, A. (2008) 'Explaining entrepreneurial intentions by means of the theory of planned behaviour', Career Development International, Vol. 13 No. 6, pp. 538-559.

Wilson, F., Kickul, J.R. and Marlino, D. (2007) 'Gender, Entrepreneurial Self-Efficacy, and Entrepreneurial Career Intentions: Implications for Entrepreneurship Education', Entrepreneurship Theory and Practice, Vol. 31 No. 3, pp. 387-407.

Wu, S. and Wu, L. (2008) 'The impact of higher education on entrepreneurial intentions of university students in China', Journal of Small Business and Enterprise Development, Vol. 15 No. 4, pp. 752-774.

Zahra, S.A., Gedajlovic, E., Neubaum, D.O. and Shulman, J.M. (2009) 'A typology of social entrepreneurs: Motives, search processes and ethical challenges', Journal of business venturing, Vol. 24 No. 5, pp. 519-532.

Zellweger, T., Sieger, P. and Halter, F. (2011) 'Should I stay or should I go? Career choice intentions of students with family business background', Journal of business venturing, Vol. 26 No. 5, pp. 521-536.

Zhao, H., Seibert, S.E. and Hills, G.E. (2005) 'The Mediating Role of Self-Efficacy in the Development of Entrepreneurial Intentions', Journal of Applied Psychology, Vol. 90 No. 6, pp. 1265-1272. 